Sharif University of Technology
Scientia Iranica
Transactions E: Industrial Engineering
SCIENTIA
I RAN I C A

\title{
Resilient logistics to mitigate supply chain uncertainty: A case study of an automotive company
}

\author{
C.Y. Hsieh ${ }^{\mathrm{a}}$, H.M. Wee ${ }^{\mathrm{b}, *}$ and A. Chen ${ }^{\mathrm{b}}$ \\ a. Department of Business, Vanung University, No.1, Wanneng Rd., Zhongli Dist., Taoyuan City 32061, Taiwan, R.O.C. \\ b. Department of Industrial and System Engineering, Chung Yuan Christian University, 200 Chung Pei Road, Chung Li District, \\ Taoyuan City, Taiwan 32023, R.O.C.
}

Received 13 August 2014; received in revised form 24 July 2015; accepted 3 November 2015

\author{
KEYWORDS \\ Process mapping; \\ Program Evaluation \\ and Review Technique \\ (PERT); \\ Resilient; \\ Supply chain \\ management.
}

\begin{abstract}
Over the years, supply chain management has become more sophisticated. As supply chains become more interconnected and globalized, they also become more vulnerable, with more potential of failure and less margin of error for absorbing delays and disruptions. Since disturbances affect the normal operation of a supply chain resulting in profit loss and poor customer satisfaction, therefore, a resilient supply chain is critical to the success of an enterprise. Natural catastrophes and man-made disasters have significantly increased over the past decades. The flood in Thailand and the unexpected tsunami/nuclear leak disaster that hit northern Japan in 2011 have resulted in huge financial losses and a decline in customer satisfaction in the car manufacturing industries in Asia Pacific and North America. To overcome the increasing uncertainty which resulted from these disasters, a study to identify risk mitigation strategies for an automotive industry is timely. Our objective was to reduce the losses due to possible disasters using an automotive industry as a case example.

(C) 2016 Sharif University of Technology. All rights reserved.
\end{abstract}

\section{Introduction}

This study aims to mitigate supply chain uncertainty in an automobile company and develop a resilient logistics. The methodology consists of two steps. The first step is to apply the mapping process to define supply chain entities, links, material flows, operating time, and costs incurred in the logistic. The second step is to select the risk mitigation strategies to reduce the costs as a result of the disasters. Then, we suggest action plans to recover from the impact of the disasters using Program Evaluation and Review Technique (PERT) model.

\footnotetext{
*. Corresponding author. Tel.: +886-3-265-4409; Fax: +886-3-265-4499

E-mail address: cishieh@vnu.edu.tw (C.Y. Hsieh); weehm@cycu.edu.tw (H.M.Wee); chenamy999@gmail.com (A. Chen)
}

Natural catastrophes and man-made disasters have significantly increased over the past decades. According to the report of Swiss Re Economic Research and Consulting on natural catastrophes and man-made disasters, losses caused by natural catastrophes ranged from US $\$ 11.8$ billion in 2006 to US $\$ 110$ billion in 2011 , and totaled US $\$ 71.2$ billion in 2012. That was an increase of $502 \%$ in major damage caused by storms, floods, and earthquakes. Figure 1 shows the history of natural catastrophes and man-made disasters. The cost of damage caused by man-made disasters also increased from US $\$ 4.04$ billion in 2006 to US $\$ 5.96$ billion in 2012, with $50 \%$ of the increase caused by fires and maritime disasters. The flood in Thailand and the unexpected tsunami/nuclear leak disaster that hit Northern Japan in 2011 resulted in huge financial losses and a decline in customer satisfaction in the car manufacturing industries in Asia Pacific and North America. Researches to mitigate supply chain uncer- 


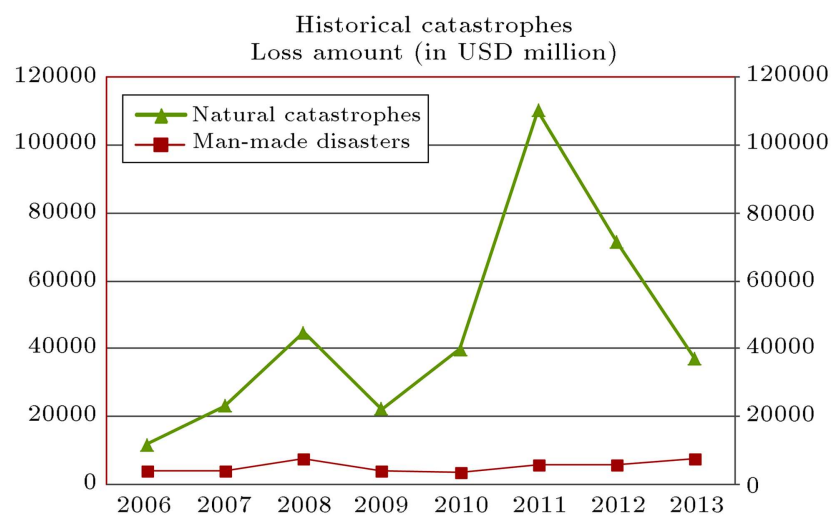

Figure 1. Historical natural catastrophes and man-made disasters (source: Swiss Re Ltd, economic research \& consulting (2014) [27]).

tainty in automobile companies are lacking. Therefore, this study, using an automotive industry as a case study, seeks to build a resilient network to mitigate supply chain risks due to disasters. The objective is to reduce losses.

The contribution of this study is to facilitate automotive industries to better manage the unpredictable disasters in their supply chain through sourcing policy and global logistic strategy. The case study and userfriendly model can provide insights to other industries to better manage disruptions in their supply chains.

\section{Literature review}

Christopher and Peck [1] defined supply chain as "the organization networks that are involved, through upstream and downstream linkages, in different processes and activities to produce finished goods and services for ultimate consumers." An automotive industry is an elaborate network that involves moving vehicles and parts from suppliers, manufacturers, wholesalers, distributors, and retailers to the final customers. A disruption in the supply chain results in a considerable loss to the automotive company. It is crucial for the senior management team of the company to identify and mitigate the sources of supply chain disruption and build a resilient supply chain.

Before building a resilient supply chain and mitigate uncertainty in an automotive network, it is vital to examine the risks prevalent in a supply chain and prioritize the risks based on intensity, vulnerability, and criticality. Deloitte and Touche [2] addressed four distinct categories of supply chain risks; they are: the macro-environment risks, the extended value chain risks, the operational risks, and the functional risks, as shown in Figure 2.

Tang and Tomlin [3] stated that operational risks refer to the inherent customer demand and cost uncertainties. The disruption risks refer to the major disruptions caused by natural and man-made disasters such as earthquakes, floods, hurricanes, and terrorist attacks; and the economic crisis refers to currency evaluation or strikes. Mason-Jones and Towill [4] addressed five categories of risk in the supply chain; internal to the firm (process and control), external to the firm but internal to the network supply chain (demand and supply), and external to the network (environment). Traditionally, enterprises focused on mitigating the operational risks and the potential disruption in the supply chains.

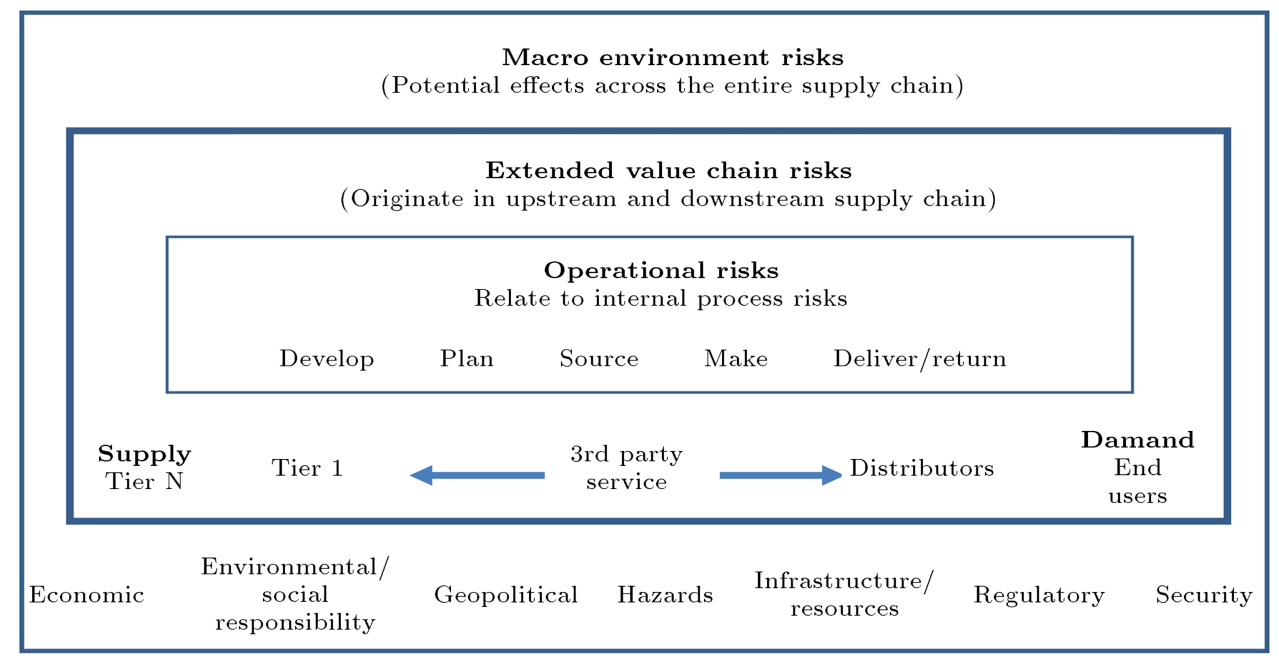

\begin{tabular}{|c|c|c|c|}
\hline \multicolumn{4}{|c|}{$\begin{array}{l}\text { Functional risks } \\
\text { Exist among enabling functions that support supply chain process }\end{array}$} \\
\hline Finance & $\begin{array}{l}\text { Human } \\
\text { resources }\end{array}$ & $\begin{array}{l}\text { Information } \\
\text { technology }\end{array}$ & Legal \\
\hline
\end{tabular}

Figure 2. Risks of supply chain (source: Deloitte development LLP (2012) [1]). 
A resilient supply chain enables companies to avoid risks or to recover from them quickly. Allenby and Fink [5] indicated that "resiliency is defined as the capability of a system to maintain its functions and structure in the face of internal and external change and to degrade gracefully when it must." Christopher and Peck [6] defined a resilient supply chain as "the ability of a supply chain network to return to its original state or move to a new, more desirable state after being disturbed." Sheffi [7] stated that "the resilience refers to the ability of a company to bounce back from a large disruption; this includes the speed with which it returns to the normal performance levels of production, services, and fill rate".

To build resilience, companies must focus on essential capabilities. Deloitte and Touche [2] identified four crucial attributes of a resilient supply chain: visibility, flexibility, collaboration, and control. In addition, they indicated that good governance, accountability, and ownership supported by strong key people, processes, and technology are critical to sustain a resilient supply chain. Sheffi [7] also indicated that "companies can develop resilience in three main ways: increasing redundancy, building flexibility, and changing corporate culture". Redundancy indicates that an organization can hold extra inventory, implement low capacity use, and retain numerous suppliers to continue operating after a disruption, however, this is a temporary, costly, and inefficient measure. A flexible supply chain allows a company to withstand disruptions and effectively responds to demand fluctuations. Resilient organizations share several cultural traits after a disruption:

1. Continual communication among informed employees;

2. Teams and individuals are empowered to take necessary actions;

3. Successful companies engender a sense of the greater good in their employees;

4. Resilient and flexible organizations are apparently conditioned.

Kim et al. [8] illustrated Graph theory to conceptualize supply network disruption and resilience by examining the structural relationships among entities in the network. Chen et al. [9] created a formal model to portray a dynamic operational performance among supply chain firms facing disruptions caused by natural and man-made disasters.

From current literature, we identified risks and the characteristics of a resilient supply chain. Then, we summarized the mitigation policy/action for the supply chain risks and the related references. The details are shown in Table 1.

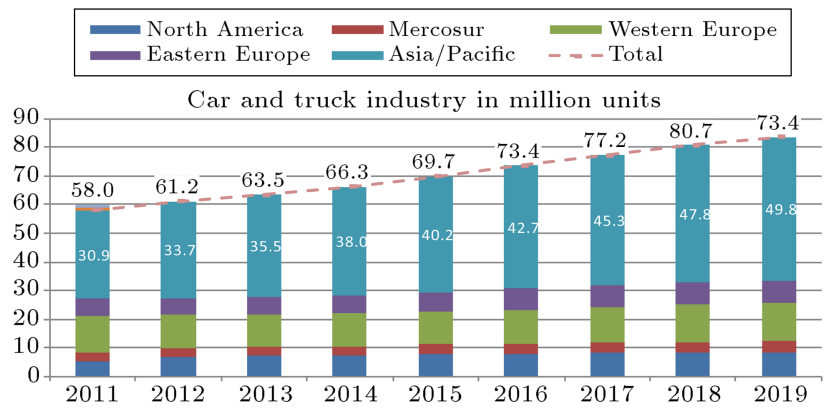

Figure 3. Car and truck industry (source: global car and truck forecast by LMC (2014) [28]).

\section{The logistic strategy by PERT model}

\subsection{Background}

The total number of cars and trucks manufactured globally in 2011 was 58 million units; it was around 66.4 million units in 2014 and will be 83.4 million units in 2019 , a $43.9 \%$ increase as compared with the growth rate from 2011 to 2014. The forecast was done by LMC Automotive based on over four hundred cars and truck makers around the world. Figure 3 shows the global growth of car and truck industry from 2011 to 2019. The Asian automotive industry was 30.5 million units in 2014, 38 billion units in 2014, and will be 49.8 billion units in 2019. Being a rapid growing economy, the automobile growth in Asia is expected to account for $61 \%$ of the global growth in the auto industry over the next five years. The details are illustrated in Figures 3 and 4 .

The automobile company under study has a forecast growth of $60-70 \%$ in the next 10 years. Asia Pacific is now the largest vehicle market in the world totalling 24 manufacturing and assembly facilities in eight markets. This automobile company expects vehicle sales to increase approximately $50 \%$ from 5.3 million in 2010 to about 8 million by mid-decade. It is predicted that nearly one-third of the company sales in 2020 will come from Asia Pacific.

Since 2006, over US $\$ 6$ billion has been invested by this automotive company in the region (including

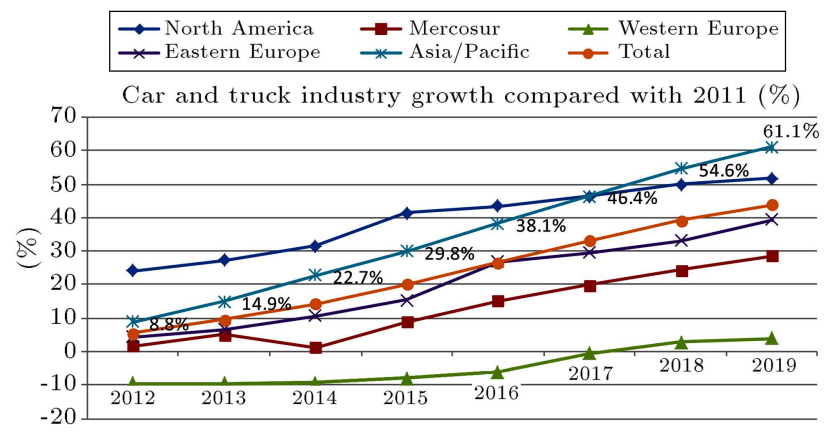

Figure 4. Car and truck industry growth compared with car industry in 2011 (source: global car and truck forecast by LMC (2014) [28]). 
Table 1. Summary of mitigation policy/action vs. supply chain risks.

\begin{tabular}{|c|c|c|}
\hline Mitigation policy/action & Supply chain risks & References \\
\hline $\begin{array}{l}\text { Information management for } \\
\text { short-life cycle products }\end{array}$ & $\begin{array}{l}\text { Risk of product delivery process - } \\
\text { control system, supply, demand, } \\
\text { manufacturing process }\end{array}$ & $\begin{array}{l}\text { Mason-Jones and } \\
\text { Towill (1998) [4] }\end{array}$ \\
\hline $\begin{array}{l}\text { Agile supply chain-network } \\
\text { based, process and virtual } \\
\text { integration, market sensitive }\end{array}$ & $\begin{array}{l}\text { Risks of time-to-market, } \\
\text { time-to-serve, time-to-react }\end{array}$ & $\begin{array}{l}\text { Christopher and } \\
\text { Peck (2004) [1] }\end{array}$ \\
\hline $\begin{array}{l}\text { Urban systems and network-centric } \\
\text { organizations }\end{array}$ & $\begin{array}{l}\text { Terrorist attacks, natural } \\
\text { disasters, tsunami }\end{array}$ & $\begin{array}{l}\text { Allenby and } \\
\text { Fink }(2005)[5]\end{array}$ \\
\hline $\begin{array}{l}\text { Supply chain reengineering, } \\
\text { collaboration, agility, } \\
\text { flexibility, risk } \\
\text { management culture }\end{array}$ & $\begin{array}{l}\text { Disruption of process, control, } \\
\text { supply and demand due to } \\
\text { man-made or natural disaster }\end{array}$ & $\begin{array}{l}\text { Christopher and } \\
\text { Pack (2004) [1], } \\
\text { Sheffi (2005) [7], } \\
\text { Tang (2006) [10] }\end{array}$ \\
\hline $\begin{array}{l}\text { Flexibility strategies - shift } \\
\text { order and production } \\
\text { quantities across supplier } \\
\text { or products and time }\end{array}$ & $\begin{array}{l}\text { Supply cost risks, } \\
\text { commitment risks, process } \\
\text { risks, demand risks }\end{array}$ & $\begin{array}{l}\text { Tang and Tomlin (2008) [3], } \\
\text { Shao (2012) [11], } \\
\text { Das (2011) [12], } \\
\text { Sting and } \\
\text { Huchzermeier (2010) [13] }\end{array}$ \\
\hline $\begin{array}{l}\text { Proactive planning team, } \\
\text { mitigation plan, continuous } \\
\text { improvement, detection, } \\
\text { response, and recovery plan }\end{array}$ & $\begin{array}{l}\text { Catastrophic events of a } \\
\text { major terrorist, strikes, } \\
\text { aircraft accidents, nuclear } \\
\text { reactor, earthquake, etc. }\end{array}$ & Knemeyer et al. (2009) [14] \\
\hline $\begin{array}{l}\text { Flexible capacity, contingency } \\
\text { plan, multiple sourcing strategy; } \\
\text { promotion, customer incentive, } \\
\text { educated customer; cost reduction } \\
\text { in operation, lobbying }\end{array}$ & $\begin{array}{l}\text { Supply risks - imports, climate, } \\
\text { man-made disasters, natural } \\
\text { disasters, socio-economic; } \\
\text { Demands risks - economic, } \\
\text { uncertainty, product hazard, } \\
\text { outbreak, forecasting errors }\end{array}$ & $\begin{array}{l}\text { Oke and Gopalakrishnan } \\
(2009)[15] \text {, Naim et al. } \\
(2010)[16]\end{array}$ \\
\hline $\begin{array}{l}\text { Multiple sourcing, alternative } \\
\text { sourcing in and out of home } \\
\text { country, outsourcing, early } \\
\text { supplier involvement, supply } \\
\text { chain design, operational hedging, } \\
\text { postponement strategy, mixed model, } \\
\text { lean manufacturing, reduced inventory } \\
\text { holding, efficient transportation, } \\
\text { supplier initiatives }\end{array}$ & $\begin{array}{l}\text { Material flow risk-source, make, } \\
\text { deliver and supply chain scope; } \\
\text { Financial flow risk-exchange rate, } \\
\text { price and cost, financial handling; } \\
\text { Information flow risk-accuracy, } \\
\text { security and disruption, } \\
\text { intellectual property }\end{array}$ & Tang and Musa (2011) [17] \\
\hline $\begin{array}{l}\text { Optimal backup depot, Multiple } \\
\text { sourcing, coverage }\end{array}$ & Uncertain location-transportation & Klibi and Martel (2012) [18] \\
\hline $\begin{array}{l}\text { Supplier order policy (multiple } \\
\text { suppliers, multiple-product- } \\
\text { multiple-stage-multiple-period, } \\
\text { lead time, capacity, and cost) }\end{array}$ & Supply and demand risks & $\begin{array}{l}\text { Sawik (2013) [19], } \\
\text { Yu et al. (2009) [20], } \\
\text { Klibi and Martel (2012) [21], } \\
\text { Xanthopoulos et al. (2012) [22], } \\
\text { Kumar and Havey (2013) [23], } \\
\text { Davarzani et al. (2011) [24], } \\
\text { Fang et al. (2013) [25] }\end{array}$ \\
\hline $\begin{array}{l}\text { Build up a decision management } \\
\text { supports for disaster relief } \\
\text { supply chain }\end{array}$ & $\begin{array}{l}\text { Natural disasters, environmental } \\
\text { threats, financial meltdowns, } \\
\text { surprise attacks }\end{array}$ & Boin et al. (2010) [26] \\
\hline
\end{tabular}


Africa). The top priority for the senior management team is to build resilient logistics to mitigate uncertainty due to vulnerable automotive industry.

\subsection{Methodology and study process}

Several root causes of the losses were highlighted by the target automotive company management team, deep dove. Two key reasons to prevent the risks incurred were identified as tooling source shared and inefficient communication in the region. The resilient logistics was suggested to overcome the problem in the tooling source shared and the complex automotive industry. The first step is to apply the mapping process to define supply chain entities, links, material flow, operating time, and costs incurred in the logistics. The second step is to select the risk mitigation strategies to reduce the costs as a result of the disasters. Then, we suggest action plans to recover from the impact of the disasters using Program Evaluation and Review Technique (PERT) model. The four stages in this study are illustrated as follows:

- Stage 1. Supply chain mapping: To quickly respond to the supply chain disturbance, supply chain mapping is described and visualized. The mapping considers:

1. Supply chain entities;

2. The links between supply chain entities;

3. Material flows;

4. Information flows;

5. Management policies;

6. Lead times.

- Stage 2. Potential disturbances identified in the supply chain: This phase focuses on the disturbances that may occur in the supply chain. Potential disturbances have a higher probability of occurring and/or high negative impact on the supply chain;

- Stage 3. Mitigation policy selected for potential disturbances: This stage identifies reactive or proactive policies to mitigate the disturbance in supply chain;

- Stage 4. Performance comparison of mitigation policies implemented: This stage examines the policies to mitigate the adverse impacts and to promote speed recovery.

\subsection{Case study}

The target Automotive Company selected five manufacturers including Thailand $j_{1}$, Taiwan $j_{2}$, South Africa $j_{3}$, Vietnam $j_{4}$, and Australia $j_{5}$ in the Asian region for study. These manufacturers share the same auto parts tooling mold in these countries; consequently, they will encounter risks if the supply chain disasters occur. Valuable lessons were learnt from the great East Japan Earthquake in March 2011 and the severe floods in Thailand in May 2012. A resilient network can mitigate the losses due to supply chain disruptions. The network of an automotive company includes several key activities, events, immediate predecessor, and crash activities. They are shown in Table 2.

\subsubsection{Logistic description}

The supply chain was defined by seventeen entities: 5 manufacturers, 1 component's kitting, 6-tier I supplier, 1-tier II supplier, and 4 port's handling. The 1st manufacturer provided $\mathrm{X}$ product to itself and four other manufacturers in Asia Pacific. X product included $\mathrm{A}$ and $\mathrm{B}$ parts. A part was produced by 1st assembler who owned the jig tooling of A parts

Table 2. Mapping process of an automotive supply chain.

\begin{tabular}{|c|c|c|c|c|c|c|c|c|}
\hline \multirow{2}{*}{ Activity } & \multirow{2}{*}{ Description } & \multirow{2}{*}{$\begin{array}{l}\text { Immediate } \\
\text { predecessor }\end{array}$} & \multirow{2}{*}{ Crash activity } & \multicolumn{5}{|c|}{ Process flow } \\
\hline & & & & $\mathbf{O}$ & $\mathbf{T}$ & $\mathbf{I}$ & $\mathbf{S}$ & $\mathbf{D}^{*}$ \\
\hline 1 & Consignment assembly & - & Over time/2nd shift/increase capacity & $\mathrm{O}$ & $\mathrm{T}$ & & $\mathrm{S}$ & $\mathrm{D}$ \\
\hline 2 & Component part supplying & $\mathrm{A}$ & Over time/2nd shift/increase capacity & $\mathrm{O}$ & $\mathrm{T}$ & & $\mathrm{S}$ & $\mathrm{D}$ \\
\hline 3 & assembler & $\mathrm{B}$ & Over time/2nd shift/increase capacity & $\mathrm{O}$ & $\mathrm{T}$ & I & $\mathrm{S}$ & $\mathrm{D}$ \\
\hline 4 & Packaging & $\mathrm{C}, \mathrm{B}$ & Over time/increase facility & $\mathrm{O}$ & & & $\mathrm{S}$ & \\
\hline 5 & Kitting & $\mathrm{D}$ & Over time/increase facility & $\mathrm{O}$ & & & $\mathrm{S}$ & \\
\hline 6 & Truck from warehouse to port & $\mathrm{D}, \mathrm{E}$ & Over time/increase frequency & & $\mathrm{T}$ & & & \\
\hline 7 & Sea freight & $\mathrm{F}$ & Premium freight & & $\mathrm{T}$ & & & \\
\hline 8 & Truck from port to warehouse & G & Over time/increase frequency & & $\mathrm{T}$ & & & \\
\hline 9 & Unboxing & $\mathrm{H}$ & Over time /increase facility & $\mathrm{O}$ & & & & \\
\hline 10 & Consignment parts assembled & $\mathrm{H}$ & Over time/2nd shift/increase capacity & $\mathrm{O}$ & $\mathrm{T}$ & & $\mathrm{S}$ & \\
\hline 11 & Material handling & $\mathrm{I}, \mathrm{J}$ & Over time/increase facility & $\mathrm{O}$ & & & & \\
\hline 12 & Assembler & $\mathrm{I}, \mathrm{K}$ & Over time/2nd shift/increase capacity & $\mathrm{O}$ & & I & $\mathrm{S}$ & $\mathrm{D}$ \\
\hline
\end{tabular}

*O: Operation (value added); T: Transportation (value added); I: Inspect (non-value added); S: Storage (non-value added);

D: Delay (non-value added). 


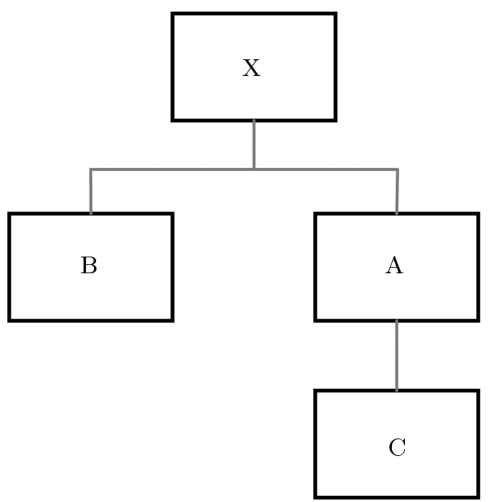

Figure 5. BOM list of $\mathrm{X}$ product.

(tier I supplier), while raw material $\mathrm{C}$ was from tier II supplier. A parts were then delivered to the kitting center by truck; B parts (tier I supplier) together as $\mathrm{X}$ product were packed for shipping by sea to other 4 manufacturers where they were unloaded and unboxed into $\mathrm{X}$ product. $\mathrm{X}$ product and local parts are then delivered to production line for vehicle production. $\mathrm{X}$ product's Bill Of Materials (BOM) tree is illustrated in Figure 5. All material flow was handled by Material Requirements Planning (MRP).

The 1st Tier A produced part A daily; the quantity produced depended on the order placed daily by 1 st assembler; the production lead time was 4 days; 2nd Tier $\mathrm{C}$ produced part $\mathrm{C}$ daily; the quantity produced depended on the order placed daily by 1st
Tier A (production lead time was 2 days). The installed maximum capacity of 1st manufacturer was 12,000 units monthly. The normal lead time to ship X product to 2nd manufacturer and 3rd manufacturer was 45 days; to 4 th and 5 th manufacturers, it was 46 days. The supply chain flow is illustrated in Figure 6.

This study analyzed the supply chain resilience and flexibility in term of response time and costs. Management teams around the Asia region aim to build a robust process to quickly mitigate disturbances in the auto industry supply chain.

\subsubsection{Performance measures}

In order to develop a resilient and proactive supply chain, key performance index is essential to assess current states and potential future state. After implementing the mitigation policies, compare the performances of the current state and the potential future states in term of supply chain cost and lead time.

The measurement applies PERT (Program Evaluation and Review Technique) using Lingo software and Excel sheet.

\subsubsection{Formulating the PERT model}

Before describing the model, the following notations are defined:

\section{- Parameters:}

$N D_{i j}$ : Normal days caused by the $i$ th activity and $j$ th assembler; $i$ Logistic activity, $i=1,2 \cdots, m$,

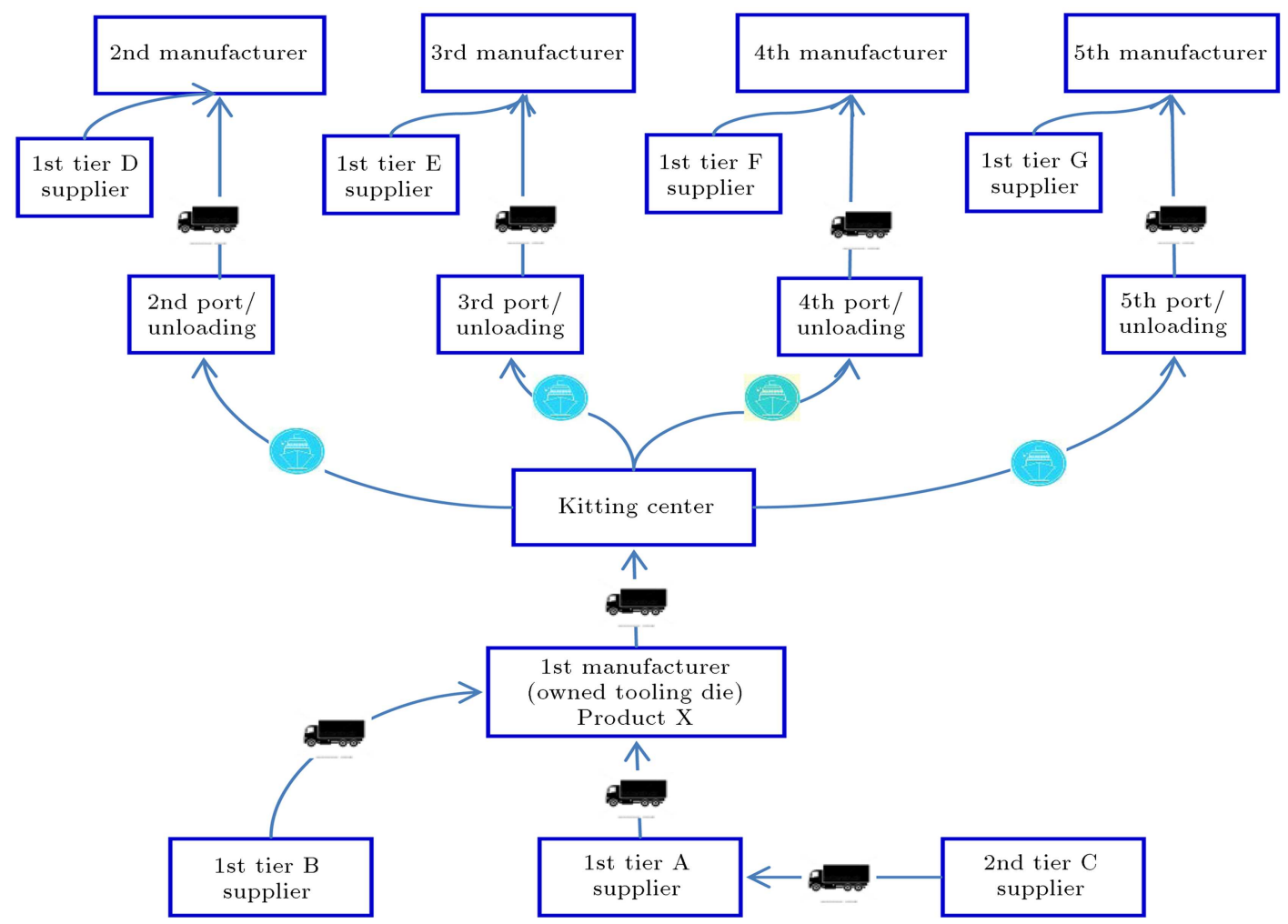

Figure 6. Auto industry supply chain. 
$i \in \mathbb{N}$, and $j$ Manufacturer, $j=1,2, \cdots, n, j \in \mathbb{N}$ $C D_{i j}$ : Crash days by the $i$ th activity and $j$ th manufacturer;

$R D_{i j}=N D_{i j}-C D_{i j}:$ Maximal reduction days caused by the $i$ th activity and $j$ th manufacturer;

$T F D_{j}$ : Maximum total finish days for $j$ th assembler in region;

$C N D_{i j}$ : Normal logistic costs caused by the $i$ th activity and $j$ th manufacturer;

$C N D_{j}=\sum_{i=1}^{m} C N D_{i j}$ : Normal logistic costs caused by $j$ th manufacturer;

$C C D_{i j}$ : Crash logistic costs caused by the $i$ th activity and $j$ th manufacturer;

$C C D D_{i j}=\left(C C D_{i j}-C N D_{i j}\right) / R D_{i j}$ : Crash logistic costs per day caused by the $i$ th activity and $j$ th manufacturer;

$C C D D_{i j}=\left(C C D_{i j}-C N D_{i j}\right) / R D_{i j}$ : Crash logistic costs per day caused by the $i$ th activity and $j$ th manufacturer;

$P U_{j}$ : Upper bound production volume by $j$ th manufacturer;

$P L_{j}$ : Lower bound production volume by $j$ th manufacturer;

\section{- Variables:}

$X S T_{i j}$ : Expected start logistic day related to the $i$ th activity for $j$ th manufacturer; $i$ logistic activity, $i=1,2, \cdots, m, i \in \mathbb{N}$, and $j$ manufacturer, $j=$ $1,2 \cdots, n, j \in \mathbb{N}$

$X S T_{i j}^{-}$: Expected start logistic day related to the immediate predecessor by the $i$ th activities for $j$ th manufacturer;

$X R D_{i j}$ : Expected reduction crash day by the $i$ th activity and $j$ th manufacturer;

$X R D_{j}=\sum_{i=1}^{m} X R D_{i j}$ : Expected reduction Crash day by $j$ th manufacturer;

$X F D_{i j}=X S T_{i j}+N D_{i j}-X R D_{i j}$ : Total finish days by the $i$ th activity and $i$ th manufacturer;

$X T F D_{j}$ : Expected finish logistic days related to the $j$ th manufacturer;

$P_{j}$ : Optimal production volume for the $j$ th manufacturer;

$T C C D_{j}=\sum_{i=1}^{m} C N D_{j}+\sum_{i=1}^{m} C C D D_{j} \times X R D_{j}:$

Total crash logistic costs by the $j$ th manufacturer.

Based on the above definitions, PERT can be represented formally as the following liner integer program:

Objective: Minimize total regional logistic costs:

$$
\begin{aligned}
\sum_{j=1}^{n} T C C D_{j} \times P_{j}= & \left(\sum_{i=1}^{m} C N D_{j}+\sum_{i=1}^{m} C C D D_{j}\right. \\
& \left.\times X R D_{j}\right) \times p_{j} .
\end{aligned}
$$

where:

$\begin{array}{ll}i & \text { Logistic activity, } i=1,2, \cdots, m, i \in \mathbb{N} ; \\ j & \text { manufacturer in region, } j=1,2, \cdots, n, \\ & i \in \mathbb{N} .\end{array}$

Subject to:

$X T F D_{j} \leq T F D_{j}$ : Expected total finish logistic days less than the maximal total finish days for $j$ th manufacturer;

$X T F D_{j} \geq X F D L_{j}$ : Expected total finish logistic days greater than the last logistic activity of $L$ for $j$ th manufacturer;

$X R D_{i j} \leq R D_{i j}$ : Expected reduction crash days less than the maximal total finish days caused by the $i$ th activity and $j$ th manufacturer;

$X S T_{i j} \geq X S T_{i j}^{-}$: Expected finish logistic days related to the logistic activities $j$ greater than the immediate predecessor by the $i$ th activity and $j$ th manufacturer; $P L_{j} \leq P_{j} \leq P U_{j}$ : Optimal production volume of $j$ th manufacturer greater lower bound production volume of $j$ th manufacturer and less than the upper bound production volume of $j$ th manufacturer.

\subsubsection{Identified actions and scenarios to mitigate the disturbance}

In this case study, 1st manufacturer suffered from flooding and $\mathrm{X}$ product was delayed. The loss impact was huge due to components delay. The management team was forced to make mitigation actions. The mitigation actions taken were working overtime, more shifts production, and changing the mode of transportation from sea to air. A total of 6 actions were identified and evaluated.

- Mitigation Action 1 (MA1): Raw material C of tier II shipped through air freight;

- Mitigation Action 2 (MA2): 1st manufacturer worked overtime to increase production capability;

- Mitigation Action 3 (MA3): Kitting through overtime increased production capability;

- Mitigation Action 4 (MA4): 2nd 5th manufacturers worked overtime to increase production capability;

- Mitigation Action 5 (MA5): 2nd 5 th manufacturers, supplier $D \sim G$, and material handling through overtime increased production capability;

- Mitigation Action 6 (MA6): Component parts were shipped by air freight instead of shipping by sea.

A total of 10 scenarios were listed for different mitigation actions taken for this case study. They were measured by using PERT.

- Scenario 1: The normal lead time to ship X product to $2 \mathrm{nd}$ and 3 rd manufacturers was 45 days, and to 4 th 
and 5 th manufacturers was 46 days; a total logistic cost was $\$ 569.95$ million;

- Scenario 2: MA1 action taken to mitigate the disruption;

- Scenario 3: MA2 action taken to mitigate the disruption;

- Scenario 4: MA3 action taken to mitigate the disruption;

- Scenario 5: MA4 action taken to mitigate the disruption;

- Scenario 6: MA5 action taken to mitigate the disruption;

- Scenario 7: MA6 action taken to mitigate the disruption;

- Scenario 8: MA1 and MA2 actions taken to mitigate the disruption;

- Scenario 9: MA1, MA2 and MA3 actions taken to mitigate the disruption;

- Scenario 10: MA1 MA6 actions taken to mitigate the disruption.

\subsubsection{Data analysis}

After implementing the mitigation actions for the disturbance in the logistics, improvement in supply chain cost and lead time was summarized in Table 3. For the mitigation actions of Scenario 2, 3, and 7, the lead time was shortened from 46 days to 43 days, a 3-day reduction, but the total logistic costs for the implemented actions were $\$ 584.74$ million for action of MA1, $\$ 586.46$ million for action of MA2, and 605.34 million for action of MA6. Supply chain costs per day for action implemented were $\$ 4.93$ million for action of MA1, $\$ 5.51$ million for action of MA2, and $\$ 11.8$ million for action of MA6.

As a result of mitigation actions for Scenarios 3, 4 , and 5 shown in Table 3, the total logistic cost of Scenario 3 (overtime) conducted by 1 st manufacturer (mitigation action of MA2) was $\$ 586.46$ million, and the total logistic cost of Scenario 5 was $\$ 590.59$ million for the mitigation action (overtime) taken by 2 nd $~ 5$ th manufacturers (MA5). We found that the total logistic cost, due to the action taken by the 1st manufacturer, was lower than the total logistic costs (overtime action) taken by the 2nd manufacturer.

In Scenario 2, where raw materials were shipped by air freight, the lead time was shortened from 46 days to 43 days; total supply chain cost was $\$ 584.74$ million, $\$ 14.79$ million higher than Scenario 1. For the mitigation action Scenario 7 (MA6), the total logistic cost was $\$ 605.34$ and the logistic cost per day was $\$ 11.8$ million; it was higher than the other mitigation actions. The total cost of raw material delivered by air freight was around 18.88 million lower than the cost of component parts shipped by air freight. If all mitigation policies were taken, the lead time would

Table 3. Performance measurement summary.

\begin{tabular}{|c|c|c|c|c|c|c|}
\hline \multirow[b]{2}{*}{ Scenario } & \multicolumn{2}{|c|}{ Characterization } & \multicolumn{4}{|c|}{ Performance measures } \\
\hline & Disturbance & Mitigation action & $\begin{array}{c}\text { Total } \\
\text { logistic cost } \\
\text { (US\$ million) }\end{array}$ & $\begin{array}{c}\text { Max } \\
\text { (lead time) } \\
\text { (days) }\end{array}$ & $\begin{array}{l}\text { Response } \\
\text { lead time } \\
\text { (days) }\end{array}$ & $\begin{array}{l}\text { Additional } \\
\text { logistic cost } \\
\text { per day } \\
\text { (US\$) }\end{array}$ \\
\hline 1 & - & & $\$ 569.95$ & $45 / 46$ & - & - \\
\hline 2 & $\mathrm{~V}$ & MA1 (supplier overtime) & $\$ 584.74$ & 43 & 3 & $\$ 4.93$ \\
\hline 3 & $\mathrm{~V}$ & MA2 (assembler 1 overtime) & $\$ 586.46$ & 43 & 3 & $\$ 5.51$ \\
\hline 4 & $\mathrm{~V}$ & MA3 (kitting overtime) & $\$ 573.26$ & 45 & 1 & $\$ 3.31$ \\
\hline 5 & $\mathrm{~V}$ & $\begin{array}{l}\text { MA4 (assembler } 2 \sim 5 \text { over } \\
\text { time) }\end{array}$ & $\$ 590.59$ & 44 & 2 & $\$ 10.33$ \\
\hline 6 & $\mathrm{~V}$ & $\begin{array}{l}\text { MA5 (supplier, material } \\
\text { handling and assembler } \\
2 \sim 5 \text { overtime) }\end{array}$ & $\$ 590.59$ & 44 & 3 & $\$ 10.33$ \\
\hline 7 & $\mathrm{~V}$ & $\begin{array}{l}\text { MA6 (air freight instead } \\
\text { of sea freight) }\end{array}$ & $\$ 605.34$ & 43 & 3 & $\$ 11.80$ \\
\hline 8 & $\mathrm{~V}$ & MA1 plus MA2 & $\$ 604.71$ & 40 & 6 & $\$ 5.79$ \\
\hline 9 & $\mathrm{~V}$ & MA1 plus MA2 plus MA3 & $\$ 611.69$ & 39 & 8 & $\$ 5.96$ \\
\hline 10 & $\mathrm{~V}$ & All MA & $\$ 722.81$ & 30 & 16 & $\$ 9.55$ \\
\hline
\end{tabular}


be shorten to 30 days, but the cost was escalated to $\$ 722.81$ million; $\$ 152.86$ million higher than the normal logistic cost for Scenario 1.

\subsubsection{Findings and contributions}

The significant findings and contributions of this study are as follows:

- One auto parts manufacturer in Asia Pacific region was identified to supply the additional resource for the automobile company during emergency needs. The assessment criteria included logistics costs, supply flexibility, production capacity, and overall investment;

- Analyzing and mapping out of the process in the supply chain network helped the automobile company to quickly respond to the risks incurred in the supply chain. We proposed the use of PERT (Program Evaluation and Review Technique) to mitigate any losses and damage through assessing time-cost and trade-offs.

This study facilitates the automotive industry to better manage unpredictable disasters in the supply chain through sourcing policy and global logistic strategy. Finally, this user-friendly model can provide an insight for other industries to better manage disruption in their supply chains.

\section{Conclusion}

Two key root causes of the target automotive company losses were highlighted by the management team. The first reason of losses was due to single tooling source shared by the auto parts manufacturers, and the second reason was due to the inefficient communication in the region. This study, using an automotive industry as a case study, has suggested answers to these two key root causes. Through comprehensive mapping process and efficient mitigation actions, the impacts caused by the disasters were reduced. PERT (Program Evaluation and Review Technique) was used to improve the communication in the region. These analytic tools gave the company a better perspective to resolve complex supply chain problems. The results in this study are consistent with several published literature. The user-friendly model can provide managerial insights for other industries to mitigate losses and quickly respond to any disruptions in their supply chains.

\section{References}

1. Christopher, M. and Peck, H. "Building the resilient supply chain", International Journal of Logistics Management, 15(2), pp.1-13 (2004).

2. Deloitte and Touche, Supply Chain Resilience: A Risk Intelligent Approach to Manage Global Supply Chains (2012).
3. Tang, S.C. and Tomlin, B. "The power of flexibility for mitigating supply chain risks", International Journal Production Economics, 116, pp. 12-27 (2008).

4. Mason-Jones, R. and Towill, D. "Shrinking the supply chain uncertainty circle", Control, pp. 17-22 (1998).

5. Allenby, B. and Fink, J. "Toward inherently secure and resilient societies", Science, 309, p. 1034 (2005).

6. Christopher, M., Lowson, R. and Peck, H. "Creating agile supply chains in the fashion industry", International Journal of Retail and Distribution Management, 32(8), pp. 367-376 (2004).

7. Sheffi, Y. "Building a resilient supply chain" Harvard Business Review 1(08) (2005).

8. Kim, Y., Chen, Y.S. and Linderman, K. "Supply network disruption and resilience: A network structural perspective", Journal of Operations Management, 3334, pp. 43-59 (2015).

9. Chen, L.M., Liu, Y.E. and Yang, S.J. "Robust supply chain strategies for recovering from unanticipated disasters", Transportation Research Parte E, 77, pp. 198-214 (2015).

10. Tang, S.C. "Review perspectives in supply chain risk management", International Journal Production Economics, 103, pp. 451-488 (2006).

11. Shao, X. "Demand-side reactive strategies for supply disruptions in a multiple-product system", International Journal Production Economics, 136, pp. 241252 (2012).

12. Das, K. "Integrating effective flexibility measures into a strategic supply chain planning model", European Journal of Operational Research, 211, pp. 170-183 (2011).

13. Sting, F. and Huchzermeier, A. "Ensuring responsive capacity: How to contract with backup suppliers", European Journal of Operational Research, 207, pp. 725-735 (2010).

14. Knemeyer, A.M., Zinn, W. and Eroglu, C. "Proactive planning for catastrophic events in supply chains", Journal of Operations Management, 27, pp. 141-153 (2009).

15. Oke, A. and Gopalarishnan, M. "Managing disruptions in supply chains: A case study of a retail supply chain", International Journal Production Economics, 118, pp. 168-174 (2009).

16. Naim, M., Aryee, G. and Potter, A. "Determining a logistics provider's flexibility capability", International Journal Production Economics, 127, pp. 39-45 (2010).

17. Tang, O. and Musa, S.N. "Identifying risk issues and research advancements in supply chain risk management", International Journal Production Economic, 133, pp. 25-34 (2011).

18. Klibi, W. and Martel, A. "Scenario-based supply chain network risk modeling", European Journal of Operational Research, 223, pp. 644-658 (2012). 
19. Sawik, T. "Selection of resilient supply portfolio under disruption risks" Omega, 101(41), pp. 259-269 (2013).

20. Yu, H., Zeng, Z. and Zhao, L. "Single or dual sourcing: decision-making in the presence of supply chain disruption risks", Omega, 37, pp. 788-800 (2009).

21. Klibi, W. and Martel, A. "Modeling approaches for the design of resilient supply networks under disruptions", International Journal Production Economics, 135, pp. 882-898 (2012).

22. Xanthopoulos, A., Vlachos, D. and Iakovou, E. "Optimal newsvendor policies for dual-sourcing supply chains: A disruption risk management framework", Computers \& Operations Research, 39, pp. 350-357 (2012).

23. Kumar, S. and Havey, T. "Before and after disaster strikes: A relief supply chain decision support framework", International Journal Production Economics, 145, pp. 613-629 (2013).

24. Davarzani, H., Zegordi, S.H. and Norrman, A. "Contingent management of supply chain disruption: effects of dual or triple sourcing", Scientia Iranica, 18(6), pp. 1517-1528 (2011).

25. Fang, J., Zhao, L., Fransoo, J.C. and Woensel, T.V. "Sourcing strategies in supply risk management: an approximate dynamic programming approach", Computers \& Operations Research, 40, pp. 1371-1382 (2013).

26. Boin, A., Kelle, P. and Whybark, D.C. "Resilient supply chains for extreme situations: Outlining a new field of study", International Journal Production Economics, 126, pp. 1-6 (2010).

27. Seiler, Y., Staib, D. and Puttaiah, M. "Progressing on the long and winding road to recovery', Sigma,
World Insurance Conference, Published by: Swiss Re Ltd, Economic Research \& Consulting, P.O. Box 8022 Zurich, Switzerland (2014).

28. Global Car and Truck Forecast. MI US: LMC Automotive Ltd. (2014).

\section{Biographies}

Chih-Ying Hsieh is an Instructor in the Department of Business at Vanung University. He received his Master of Science in Political Economy from the National Sun-Yat-San University. His research interests are in the field of supply chain risk management and inventory control.

Hui-Ming Wee is a distinguished Professor of Industrial Engineering in Chung Yuan Christian University in Taiwan. He received his BSc in Electrical and Electronic Engineering from Strathclyde University (UK), an MEng in Industrial Engineering and Management from Asian Institute of Technology (AIT), and a $\mathrm{PhD}$ in Industrial Engineering from Cleveland State University, Ohio (USA). His research interests are in the field of production/inventory control, optimization, and supply chain management.

Amy Chen received her Master of Business Administration from Chung Yuan Christian University (CYCU), Taiwan. She is a doctoral student in the Department of Industrial and Systems Engineering in CYCU as well as a manager of Industrial Engineering in a global automotive company. Her research interests are in the field of supply chain risk management and inventory control. 